ScIDice

\section{Assessment of Microbial adhesion on 3M and Kids Stainless Steel Preformed Crowns-An In-vitro Study}

Indumathy Pandiyan ${ }^{1}$, S.S Raj ${ }^{2 *}$, Pradeep KumarRathinavelu ${ }^{3}$

${ }^{1}$ Post-Graduate Student, Department of Public Health Dentistry, Saveetha Dental College \& Hospital, Vellapanchavi, Chennai-600077, Tamilnadu, India.

${ }^{2}$ Reader, Department of Public Health Dentistry, Saveetha Dental College \& Hospital, Vellapanchavi, Chennai-600077, Tamilnadu, India.

${ }^{3}$ Professor, Department of Public Health Dentistry, Saveetha Dental College \& Hospital, Vellapanchavi, Chennai-600077, Tamilnadu, India.

\title{
Abstract
}

Introduction: Finding a dental materialwhich is appropriate with a minimal adhesion and colonization of Streptococcus mutans (S. mutans) and other pathogenic bacteria is of greater significance.The aim of the study is to evaluate the microbial adhesion on the $3 \mathrm{M}$ stainless steel crown (SSC) and Kids crown in primary molars.

Materials and Methods: This in vitro experimental study was conducted on 10 specimens in two groups (3M stainless steel crown (SSC) and Kidsstainless steel crown) exposed to S. mutans bacterial suspension $(1 \times 106 \mathrm{mg} / \mathrm{mL})$. The mitis salivarius bacitracin agar was used for the incubation of specimens, and the total number of Streptococcus mutans was counted and expressed in colony forming units (CFU).

Results: There was no statistically significant difference found in the microbial count between the 3M and Kids SS crown. Conclusion: The microbial adhesion of S. mutans was seen higher on the Kids SS crownthan 3M SS crown.

\section{Introduction}

Bacterial adhesion plays a considerable role in tooth decay, calculus formation and gingival inflammation [1-4]. Streptococcus mutans, which is the most prevailingmicroorganism in dental plaque of patients with active caries, plays a major role in the onset of dental caries and gingival inflammation [5,6]. Among the bacteria present in dental plaque, streptococci often show great adhesion to oral surfaces such as oral mucosa and dental structures[7]. Crowns are generally classified into four groups: partial veneers, full metals, metal ceramics, and all-ceramics[8]. Determination of suitable dental material limiting colonization of S. mutans is critical in patients at high risk of caries.

Stainless steel crowns (SSCs) were introducedby Humphrey in 1950 to pediatric dentistry. Since time, SSCs have become apriceless restorative technique for the treatment of badly broken down primary teeth. The superiority and durability of SSCs over multisurface amalgam and other restorations in the primary dentition has been documented in the literature[9]. Adhesion and colo- nization of oral microbes on tooth surfaces and restoratives is considered crucial in the development of secondary caries and periodontal disease[10]. In vivo and in vitro experimentshave shown that Streptococcus mutans is one of the microbes isolated in plaque samples from natural and artificial surfaces during early phases of caries development. However, it is notable that the first stage of colonization by an organism includes adherence of the organism to a host surface.

From this viewpoint, evaluation of S. mutans adhesion to tooth surfaces and restorative materials is of most importance for their success [11]. The initial adhesion and retention of S. mutanshappens through van der Waal's attractive forces and electrostatic repulsive forces with the crown surface. Further, the microorganisms present on rough surfaces of prostheses are more ensured against shear forces which permits it to be in direct contact with them for longer periods building up an oral ecological change [12]. The higher the surface free energy, the higher will be the adhesion of microorganisms, and alternatively, the more hydrophobic the surface, the less microorganism adherence is expected[13].

*Corresponding Author:

Dr.S.S Raj MDS

Reader, Department of Public Health Dentistry, Saveetha Dental College \& Hospital, Vellapanchavi, Chennai-600077, Tamilnadu, India.

E-mail: samuelrajs.sdc@saveetha.com

Received: May 04, 2021

Accepted: July 09, 2021

Published: July 16, 2021

Citation: Indumathy Pandiyan, S.s Raj, Pradeep Kumarrathinavelu. Assessment Of Microbial Adhesion On 3M And Kids Stainless Steel Preformed Crowns In-Vitro Study. Int J Dentistry Oral Sci. 2021;8(7):3206-3208. doi: http://dx.doi.org/10.19070/2377-8075-21000653

Copyright: S.S Raj MDS ${ }^{\circ}$ 2021. This is an open-access article distributed under the terms of the Creative Commons Attribution License, which permits unrestricted use, distribution and reproduction in any medium, provided the original author and source are credited. 
SSCs are available under various brands in the market like $3 \mathrm{M}$ ESPE, Unitek, Rocky Mountain, ION Ni Chro. The 3M ESPE crown is the most commonly used. Marginal adaptation is required to inhibit the ingress of oral bacteria which can cause secondary caries and gingival inflammation[14].

These preformed crowns are well contoured and are accessible in different sizes for primary teeth. Alternative SSCs such as Kids crown are introduced with thin cervical margin and makes trimming and contouring simple and convenient [15]. However, the microbial plaque adhesion on these types of crowns is unknown. Hence, the study aims to evaluate the microbial adhesion on the $3 \mathrm{M}$ SSC and Kids crown in primary molars.

\section{Materials And Methods}

This in-vitro study was carried out at the Dental Materials Research Lab of Saveetha Institute of Medical and Technical Sciences in the month of November 2020. Ethical approval was obtained from the Institute Scientific Review Board. Ten stainless steel crowns of the first primary mandibular molar of size 6 of two commercial brands named Kids crown(Shinhung, Seoul, Korea) and 3M Stainless Steel Primary Molar Crowns(3M ESPE, St. Paul, MN, USA) were used in the study. The samples were rinsed with distilled water and autoclave-sterilized. Then, they were exposed to a typical bacterial suspension of S. mutans (RTCC1683) with a concentration of $1 \times 106 \mathrm{mg} / \mathrm{mL}(0.5 \mathrm{McF}$ arland standard). The specimen was immersed in a test tube of $350 \mathrm{~mL}$ of the bacterial suspension. The tubes were incubatedat $37^{\circ} \mathrm{C}$ for one hour.Then, they were all rinsed and immersed in normal saline for 20 seconds; subsequently each sample was shaken for one minute in $1 \mathrm{~mL}$ of freshnormal saline solution;Finally, S. mutans were counted and expressed in colony forming units (CFU) (Figure 1).

\section{Results}

Two groups of $3 \mathrm{M}$ stainless steel crown and Kids stainless steel crown $(n=10)$ were tested for the adhesion of S.mutans. The mean S. mutans adhesion level to $3 \mathrm{M}$ stainless steel crown was $5.4 \pm 2.05$ colonies $/ \mathrm{mm} 2$ which was significantly lesser than that of Kids stainless steel crown with the microbial adhesion of 5.7 \pm 2.47 colonies $/ \mathrm{mm} 2$. The independent $\mathrm{t}$ - test results revealed that the difference between the mean $\mathrm{S}$. mutans adhesion to $3 \mathrm{M}$ stainless steel crown samples and to Kinder stainless steel crown samples was not significant $(\mathrm{P}=0.6)$ (Table 1$)$.

\section{Discussion}

Restoration of severely decayed primary teeth is usually a challenge to the clinician. The ideal requisites for a restoration to be successful is its durability, ease of placement, cost effectiveness, and natural appearance [16]. Preformed SSCs have better success rate than large multi surface amalgam restorations, which has been reviewed in the literature [17]. The SSC is cost effective as they are durable, inexpensive, and less technique sensitive and have high longevity than large multi surface restorations [18].

In the last few decades, an esthetic solution was found to replace the conventional SSC which has poor esthetic appearance [19]. In this regard, open faced SSCs, preveneered crowns, and resin bonded composite facings are introduced. However, a study by Reeves has shown that the esthetic crowns are more thick and bulky, which favored the adhesion of microbes causing periodontal breakdown[20].

The dental caries is caused by a principle microbe, S. mutans. The initial stage of developing secondary caries is due to the capability of S. mutans to adhere to the surface of the restoration [21,22] MSBA agar was used to isolate S. mutansbecause it is that the selective media for Streptococcus due to the addition of bacitracin and sucrose [23]. When the microbial count was seen on the crowns, there was no statistically significant difference seen between the $3 \mathrm{M}$ and Kids crown. However, the S. mutans count on the Kids crown was more than that observed on 3M crowns. Pedrini et al. said that the substances released by the dental material can directly influence the bacterial growth [24]. The characteristics of SSCs like surface roughness and surface energy influence the microbial growth [25].

Myers et al. [26] reported that plaque will readily form on the surface of SSC regardless of the polishing procedures; therefore, oral hygiene procedures should be emphasized to minimize the accumulation of plaque. This could be due to physicochemical interaction through electrostatic and van der Waals forces between the surface of the restoration and microorganisms. The characteristics of SSCs such as surface roughness and surface energy influence the microbial growth. The higher the surface area and surface roughness of the restoration, the higher is the occurrence of bacterial adhesion.

To the best of our knowledge, very few previous study has evalu-

Figure 1: CFU count (S. mutans) on 3M SS crown (1A) and Kids SS crown (1B)

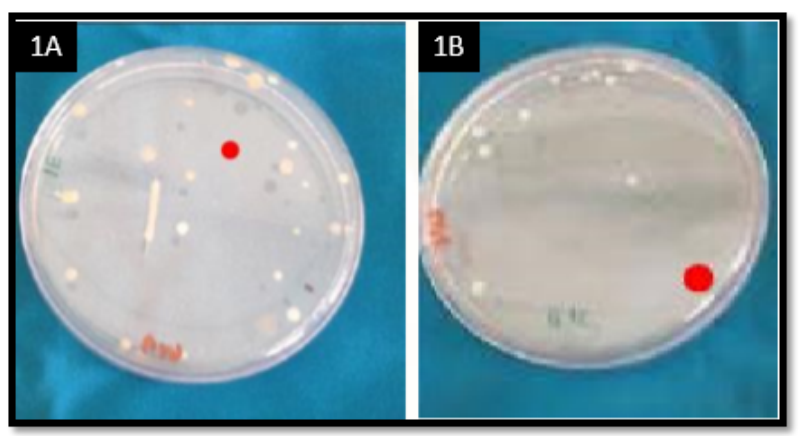


Table 1: Comparison of the adhesion level of S. mutans to $3 \mathrm{M}$ stainless steel crown and Kids stainless steel crown

\begin{tabular}{|c|c|c|}
\hline Materials used & Mean adhesion level & P value \\
\hline $\begin{array}{c}\text { 3M stainless } \\
\text { steel crown }\end{array}$ & $5.4 \pm 2.05$ colonies $/ \mathrm{mm} 2$ & 0.6 \\
\cline { 1 - 1 } $\begin{array}{c}\text { Kidsstainless } \\
\text { steel crown }\end{array}$ & $5.7 \pm 2.47$ colonies $/ \mathrm{mm} 2$ & \\
\hline
\end{tabular}

ated the microbial adhesion to SSC in primary molars, where Bin AlShaibah et al. compared microbial adhesion with SSC and preveneered SSC and concluded that preveneered SSC showed higher microbial adhesion due to the greater thickness of the crown compared with SSC (4). Subramanyam D et al. (15) reported that the microbial adhesion of S. mutans was higher on the Kids crown than $3 \mathrm{M}$ crown which was in accordance with our results.

\section{Conclusion}

Under the limitations of this investigation,the conclusion drawn is:

- Adhesion ofS. mutans was seen higher on the kidsSS crown than 3M SS crown.

- There was no significant difference between 3M and Kids crown.

\section{References}

[1]. Bollen CM, Lambrechts P, Quirynen M. Comparison of surface roughness of oral hard materials to the threshold surface roughness for bacterial plaque retention: a review of the literature. Dent Mater. 1997 Jul;13(4):258-69. Pubmed PMID: 11696906

[2]. Stenudd C, Nordlund A, Ryberg M, Johansson I, Källestål C, Strömberg N. The association of bacterial adhesion with dental caries. J Dent Res. 2001 Nov;80(11):2005-10. Pubmed PMID: 11759011.

[3]. Jalalian E, Mostofi SN, Shafiee E, Nourizadeh A, Nargesi RA, Ayremlou S. Adhesion of streptococcus mutans to Zirconia, Titanium alloy and some other restorative materials:"An in-vitro study". Advances in Bioscience and Clinical Medicine. 2015 Apr 1;3(2):13-20.

[4]. Bin AlShaibah WM, El-Shehaby FA, El-Dokky NA, Reda AR. Comparative study on the microbial adhesion to preveneered and stainless steel crowns. J Indian Soc Pedod Prev Dent. 2012 Jul-Sep;30(3):206-11. Pubmed PMID: 23263423.

[5]. Hatta H, Tsuda K, Ozeki M, Kim M, Yamamoto T, Otake S, et al. Passive immunization against dental plaque formation in humans: effect of a mouth rinse containing egg yolk antibodies (IgY) specific to Streptococcus mutans. Caries Res. 1997;31(4):268-74. Pubmed PMID: 9197932.

[6]. Pannu P, Gambhir R, Sujlana A. Correlation between the salivary Streptococcus mutans levels and dental caries experience in adult population of Chandigarh, India. Eur J Dent. 2013 Apr;7(2):191-195. Pubmed PMID: 24883025.

[7]. Braga RR, Cesar PF, Gonzaga CC. Mechanical properties of resin cements with different activation modes. J Oral Rehabil. 2002 Mar;29(3):257-62. Pubmed PMID: 11896842.

[8]. Shillingburg HT, Sather DA. Fundamentals of Fixed Prosthodontics [nternet].

[9]. Messer LB, Levering NJ. The durability of primary molar restorations: II Observations and predictions of success of stainless steel crowns. Pediatr Dent. 1988 Jun;10(2):81-5. Pubmed PMID: 3269527.

[10]. Gibbons RJ, van Houte J. Bacterial adherence and the formation of dental plaques. InBacterial adherence 1980 (pp. 61-104). Springer, Dordrecht.

[11]. Brambilla E, Cagetti MG, Gagliani M, Fadini L, García-Godoy F, Strohmenger L. Influence of different adhesive restorative materials on mutans streptococci colonization. Am J Dent. 2005 Jun;18(3):173-6. Pubmed PMID: 16158808 .

[12]. Kim DH, Kwon TY. In vitro study of Streptococcus mutans adhesion on composite resin coated with three surface sealants. Restorative dentistry \& endodontics. 2017 Feb 1;42(1):39-47.

[13]. Pereira-Cenci T, Del Bel Cury AA, Crielaard W, Ten Cate JM. Development of Candida-associated denture stomatitis: new insights. J Appl Oral Sci. 2008 Mar-Apr;16(2):86-94. Pubmed PMID: 19089197.

[14]. Loesche WJ. Microbiology of Dental Decay and Periodontal Disease. In: Baron S, editor. Medical Microbiology [Internet]. Galveston (TX): University of Texas Medical Branch at Galveston; 2011.

[15]. Subramanyam D, Gurunathan D. Microbial evaluation of plaque on 3M ESPE and kids stainless steel crown in primary molars. International Journal of Pedodontic Rehabilitation. 2016 Jul 1;1(2):60.

16]. Myers DR. A clinical study of the response of the gingival tissue surrounding stainless steel crowns. ASDC J Dent Child. 1975 Jul-Aug;42(4):281-4. Pubmed PMID: 1099129.

[17]. Papathanasiou AG, Curzon ME, Fairpo CG. The influence of restorative material on the survival rate of restorations in primary molars. Pediatr Dent. 1994 Jul-Aug:16(4):282-8. Pubmed PMID: 7937261.

[18]. Ram D, Peretz B. Composite crown-form crowns for severely decayed primary molars: a technique for restoring function and esthetics. J Clin Pediatr Dent. 2000 Summer;24(4):257-60. Pubmed PMID: 11314407.

[19]. Fuks AB, Ram D, Eidelman E. Clinical performance of esthetic posterior crowns in primary molars: a pilot study. Pediatr Dent. 1999 NovDec;21(7):445-8. Pubmed PMID: 10633519.

[20]. Reeves WG. Restorative margin placement and periodontal health. J Prosthet Dent. 1991 Dec;66(6):733-6. Pubmed PMID: 1805020.

[21]. Kawashima M, Hanada N, Hamada T, Tagami J, Senpuku H. Real-time interaction of oral streptococci with human salivary components. Oral Microbio Immunol. 2003 Aug;18(4):220-5. Pubmed PMID: 12823797.

[22]. Nyvad B, Kilian M. Comparison of the initial streptococcal microflora on dental enamel in caries-active and in caries-inactive individuals. Caries Res. 1990;24(4):267-72. Pubmed PMID: 2276164.

[23]. Wan AK, Seow WK, Walsh LJ, Bird PS. Comparison of five selective media for the growth and enumeration of Streptococcus mutans. Aust Dent J. 2002 Mar;47(1):21-6. Pubmed PMID: 12035953.

[24]. Pedrini D, Gaetti-Jardim Júnior E, de Vasconcelos AC. Retention of oral microorganisms on conventional and resin-modified glass-ionomer cements. Pesqui Odontol Bras. 2001 Jul-Sep;15(3):196-200. Pubmed PMID: 11705266.

[25]. Padbury A Jr, Eber R, Wang HL. Interactions between the gingiva and the margin of restorations. J Clin Periodontol. 2003 May;30(5):379-85. Pubmed PMID: 12716328

[26]. Myers DR, Schuster GS, Bell RA, Barenie JT, Mitchell R. The effect of polishing technics on surface smoothness and plaque accumulation on stainless steel crowns. Pediatr Dent. 1980 Dec;2(4):275-8. Pubmed PMID: 6941003. 